\title{
The Major Pelvic Ganglion: Androgen Control of Postnatal Development
}

\author{
James E. Melvin ${ }^{1, a}$ and Robert W. Hamill ${ }^{2}$ \\ Monroe Community Hospital and 'Departments of Neurobiology and Anatomy and 'Neurology, University of Rochester \\ Medical Center, Rochester, New York 14642
}

Previously we reported the effects of postnatal castration on the postorganizational development of the sympathetic hypogastric ganglion (Hamill and Guernsey, 1983; Melvin and Hamill, 1986). "Postorganization" implies an activational role for gonadal hormones, in contrast to the permanent organizing effects that occur perinatally. We now report results that suggest that the major pelvic ganglion (PG), a mixed parasympathetic and sympathetic ganglion, is similarly regulated by testosterone during development. Choline acetyltransferase (CAT) and tyrosine hydroxylase (T-OH) activities were used to examine normal PG ontogeny. The normal development of these biochemical indices occurs primarily after day 10 .

Postnatal castration at $10-11 \mathrm{~d}$ of age completely prevented the postorganizational developmental increase of $\mathrm{T}-\mathrm{OH}$ activity. At 12 postoperative weeks $\mathrm{T}-\mathrm{OH}$ activity in castrates was approximately $6 \%$ that of the control animals (control, $2880 \pm 127 \mathrm{pmol} /$ ganglion $\cdot \mathrm{hr}$; castrated, $161 \pm 16$ pmol/ganglion $\cdot$ hr; $p<0.001$ ). In fact, by only 1 postoperative week, $\mathrm{T}-\mathrm{OH}$ activity was already significantly reduced in castrated animals (control, $480 \pm 69 \mathrm{pmol} / \mathrm{ganglion} \cdot \mathrm{hr}$; castrated, $179 \pm 6 \mathrm{pmol} / \mathrm{ganglion} \cdot \mathrm{hr} ; \boldsymbol{p}<0.001$ ). CAT activity and total ganglion protein were also significantly reduced by 1 postoperative week. In contrast to T-OH activity, however, these indices continued to develop at diminished rates. By 12 postoperative weeks CAT activity and total ganglion protein in castrates were 30 and $50 \%$ of control values, respectively, resulting in a significant developmental abnormality in CAT-specific activity. Testosterone replacement reversed the castration-induced developmental deficits of T-OH and CAT activities.

These results suggest that hormonal mechanisms regulate the postorganizational development of the major pelvic ganglion. The PG appears to be dependent on testosterone and/or its metabolites for developmental increases of CAT

\footnotetext{
Received Dec. 9, 1985; revised Dec. 31, 1986; accepted Jan. 8, 1987.

We wish to thank Charlotte Melvin, Jean Van Loan, and June Carey for their exceptional secretarial services, and Linda Guernsey for her technical assistance. Testosterone decanoate was a gift of Organon Ltd., Holland. This work was supported in part by Grant NRSA DE05387-02 from the National Institute of Dental Research, Grant NS22103 from the NIH, and the Monroe Community Hospital Research Fund.

Correspondence should be addressed to Dr. Robert W. Hamill, Monroc Community Hospital, 435 East Henrietta, Rochester, NY 14603.

a Present address: National Institute of Dental Research, Bldg. 10, Room 1A05, Bethesda, MD 20892.
}

Copyright $@ 1987$ Society for Neuroscience $0270-6474 / 87 / 061607-06 \$ 02.00 / 0$ and T-OH activities, whereas total ganglion protein is apparently not fully dependent on the presence of testosterone.

Neurotransmitter-synthesizing enzyme activities in the sympathetic hypogastric ganglion (HG) have previously been shown to be highly dependent on androgens for normal development (Hamill and Guernsey, 1983; Melvin and Hamill, 1986) and adult maintenance (Hamill et al., 1984). Tyrosine hydroxylase $(\mathrm{T}-\mathrm{OH})$ activity, an index for postsynaptic noradrenergic ontogeny (Black et al., 1972; Black and Geen, 1973), has failed to develop following postnatal castration (Hamill and Guernsey, 1983; Melvin and Hamill, 1986), while choline acetyltransferase (CAT) activity, a marker for presynaptic cholinergic maturation in sympathetic ganglia (Black et al., 1971a), has continued to develop, but at a diminished rate (Melvin and Hamill, 1986). Testosterone restored both adult and postnatal castration enzyme activity deficits (Hamill et al., 1984; Melvin and Hamill, 1986). Taken together, the above results suggest that testosterone is necessary both for adult maintenance and the normal development of ncurotransmitter-synthesizing enzymes in the HG. In order to determine whether neurotransmitter-synthesizing enzymes in other pelvic autonomic ganglia are androgendependent during development, we studied the major pelvic ganglion (PG), a ganglion containing both parasympathetic and sympathetic components.

The major pelvic ganglion, located at the posterolateral border of the prostate in Inale rats, receives the main sacral parasympathetic outflow via the nervi erigentis. In addition, the PG, although classically defined as a parasympathetic ganglion, receives input from the sympathetic nervous system via the hypogastric nerve (Langworthy, 1965; Purinton et al., 1973). These preganglionic sympathetic fibers presumably innervate the catecholamine-positive neurons within the PG. The preganglionic parasympathetic fibers, in contrast, synapse on cholinergic cell bodies within the PG. Thus, within the PG, CAT enzyme activity serves as a marker of preganglionic and postganglionic parasympathetic components, as well as of preganglionic sympathetic terminals. Postganglionic fibers originating from the PG innervate pelvic accessory sex organs, as well as nonandrogen-sensitive target tissues such as the rectum and bladder. Previous studies suggest that the PG is sensitive to gonadal hormones during development. Postnatal testosterone treatment of developing rats increases both cell size and catecholamine histofluorescence in males but not females (Hervonen et al., 1972; Partanen and Hervonen, 1979a). Prepubertal orchiectomy decreases catecholamine histofluorescence and produces smaller 
than normal noradrenergic neurons (Partanen and Hervonen, 1979b). Testosterone replacement completely reverses the effects of castration on catecholamine histofluorescence and cell size. The PG may also be permanently organized by gonadal hormones, since male rats have approximately 2.5 times as many neurons as do female rats (Greenwood et al., 1985). In addition, both prenatal testosterone propionate and diethylstilbestrol administration have becn shown to increase the number of PG neurons in mice (Suzuki et al., 1982).

The studies cited above focus primarily on the noradrenergic component of the PG; similar studies of the cholinergic component are not available. Also, these reports describe the effects of testosterone treatment and castration on PG catecholamine histofluorescence. Catecholamine histofluorescence can be employed to estimate the concentration of noradrenergic neurotransmitter, but does not reflect the levels of noradrenergic synthesizing and metabolizing enzymes or the state of the neurotransmitter reuptake mechanism. Thus, changes in fluorescence can suggest either an altered synthetic rate or a change in transmitter turnover. T-OH activity has previously been employed to monitor noradrenergic development in sympathetic ganglia (Black and Geen, 1973; Hamill et al., 1977; Melvin and Hamill, 1986). Therefore, in order to compare prior studies of PG development and to determine the effect of neonatal castration on the biochemical maturation of noradrenergic synthesizing enzymes in the PG, T-OH and DOPA decarboxylase (DDC) activities were examined subsequent to castration at 10$11 \mathrm{~d}$ of age. The development of ganglionic CAT activity following castration was studied as well to assess the hormonal regulation of the cholinergic components of the $P G$.

\section{Materials and Methods}

Experimental animals. Postnatal Sprague-Dawley male rats, obtained from Charles River Laboratories, Boston, MA, were subjected to either bilateral castration or sham operation under halothane anesthesia at $10-11 \mathrm{~d}$ of age. At $21 \mathrm{~d}$ of age they were weaned and housed, 3-5 rats/ cage, with free access to food and water. Although puberty begins at approximately day 35 , adult sexual maturity is considered to occur at 60-75 d. Rats were maintained in a temperature-controlled environment $\left(24 \pm 1^{\circ} \mathrm{C}\right)$ and exposed to $12 \mathrm{hr}$ of light daily. For testosterone replacement studies, animals were injected with either $0.1 \mathrm{ml}$ of vehicle (soybean oil) or testosterone decanoate $(20 \mathrm{mg} / \mathrm{kg})$ on the day of surgery and every 2 weeks until killed. Prior to assay animals were killed by exposure to ether vapor.

Surgical procedures. Animals were anesthetized with $3.0 \%$ halothane in $100 \%$ oxygen and underwent cither sham-operation or bilateral castration that preserved the vas deferens and epididymus. The surgical approach required bilateral abdominal incisions inferior and lateral to the umbilicus. Surgical wounds were closed with flexible collodion. The major pelvic ganglia were removed from their location next to the posterolateral border of the prostrate with the aid of a dissecting microscope.

Biochemical procedures. All enzyme activities were measured using aliquots from the same ganglion. Normal neurochemical development was determined by assaying all time points together, thus eliminating interassay variation. Hormonal manipulation studies (castration and hormone replacement) measured enzyme activities for different time points separately. CAT activity was assayed using minor modifications (Melvin and Hamill, 1986) of the methods of Fonnum $(1969,1975)$. T-OH activity was assaycd using modifications (Melvin and Hamill, 1986) of previously described methods (Black et al., 1971a; Black, 1975). DDC activity was assayed according to the methods of Lamprecht and Coyle (1972). Total protein estimates were performed according to Lowry et al. (1951), with BSA as standard.

Statistics. Data were analyzed employing Student's $t$ test. Multiple data were analyzed with a 1 -way analysis of variance and the NewmanKeuls test.

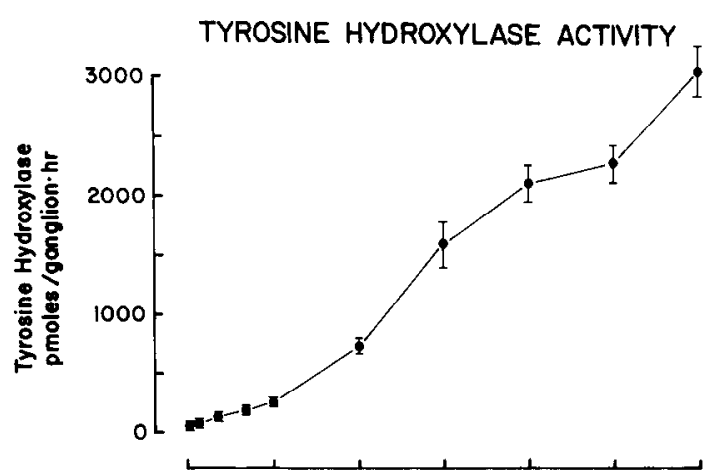

CHOLINE ACETYLTRANSFERASE ACTIVITY

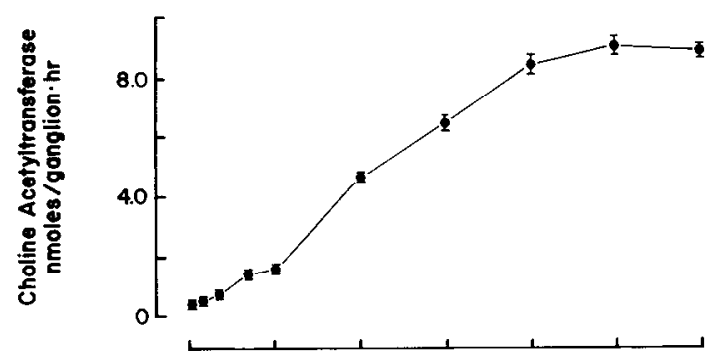

TOTAL PROTEIN

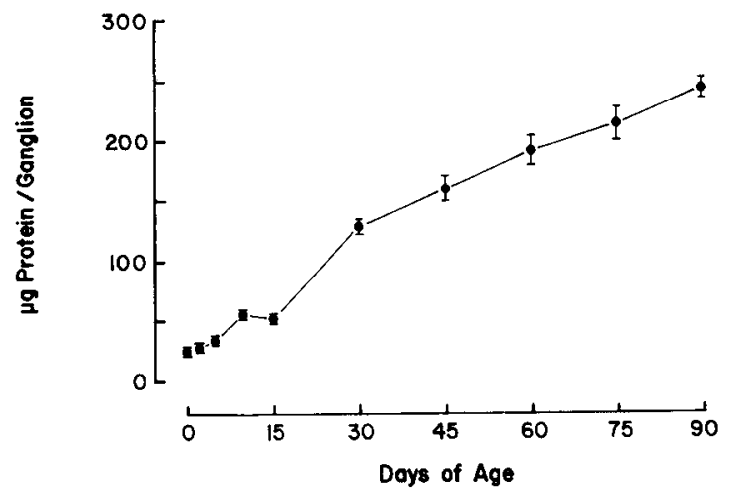

Figure 1. Developmental increases of tyrosine hydroxylase (T-OH) and choline acetyltransferase (CAT) activities and total protein in the major pelvic ganglion. Groups of 5 or 10 male rats were taken from litters of varying ages, and the ganglia from each animal were assayed for $\mathrm{T}-\mathrm{OH}$ and CAT activities and total protein. T-OH activity is expressed as $\mathrm{pmol} / \mathrm{ganglion} \cdot \mathrm{hr} \pm \mathrm{SEM}$. CAT activity is expressed as nmol/ ganglion $\cdot \mathrm{hr} \pm \mathrm{SEM}$. Total protein is expressed as $\mu \mathrm{g} / \mathrm{ganglion} \pm \mathrm{SEM}$.

\section{Results}

\section{Normal development}

The normal biochemical development of the pelvic ganglion was initially defined. Ten groups of 5-10 male Sprague-Dawley rats from litters of different ages were randomly selected and $\mathrm{T}$ $\mathrm{OH}$ activity, CAT activity, and total ganglion protein determined. Day $0,2,5,10$, and 15 time points represent a pooled sample of 4 ganglia from 2 animals. All other time points were obtained from 5 individual ganglion samples; thus all time points represent 5 separate samples. T-OH and CAT activity increased approximately 110 - and 50-fold, respectively, between the day of birth and $90 \mathrm{~d}$ of age, while ganglion protein increased 10fold (Fig. 1). The CAT activity increase displayed a constant slope, reaching an adult plateau by $60 \mathrm{~d}$ of age. In contrast to $\mathrm{CAT}$ activity, $\mathrm{T}-\mathrm{OH}$ activity rose continuously without reaching 


\section{TYROSINE HYDROXYLASE SPECIFIC ACTIVITY}

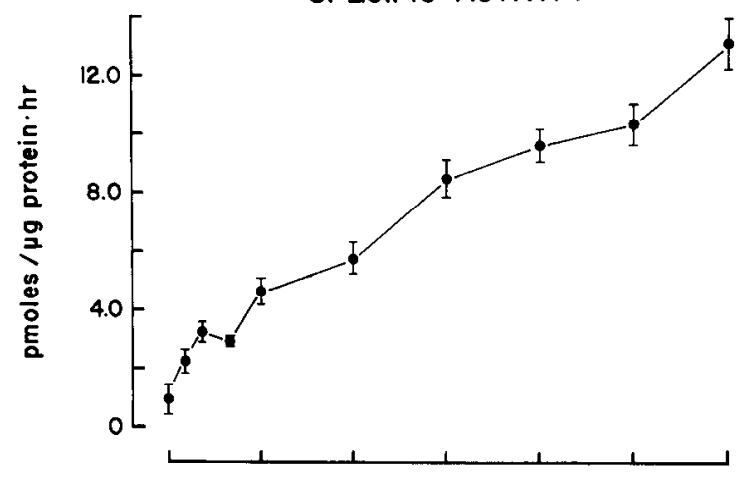

CHOLINE ACETYLTRANSFERASE SPECIFIC ACTIVITY

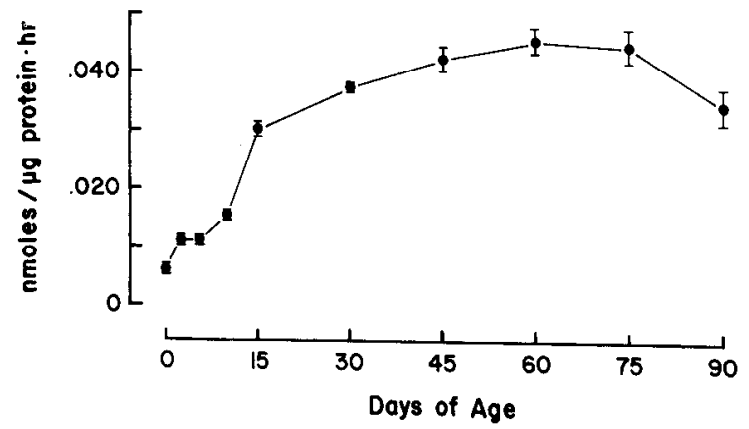

Figure 2. Development of tyrosine hydroxylase- and choline acetyltransferase-specific activities in the major pelvic ganglion. Groups of 5 or 10 male rats were taken from litters of varying ages, and the ganglia from each animal were assayed for T-OH and CAT activities and total protein. $\mathrm{T}-\mathrm{OH}$-specific activity is expressed as $\mathrm{pmol} / \mu \mathrm{g}$ protein $\cdot \mathrm{hr} \pm$ $\mathrm{SEM}$. CAT-specific activity is expressed as $\mathrm{nmol} / \mu \mathrm{g}$ protein $\cdot \mathrm{hr} \pm \mathrm{SEM}$.

an adult plateau during the first $90 \mathrm{~d}$. In addition, the development of $\mathrm{T}-\mathrm{OH}$ activity was preceded by CAT activity. CAT activity at days 30 and 45 is approximately 55 and $70 \%$ of the adult plateau level, while $\mathrm{T}-\mathrm{OH}$ activity at days 30 and 45 is 25 and $55 \%$ of the 90 d value. A significant rise in T-OH- and CAT-specific activities resulted, as compared with ganglion protein (Fig. 2), because of the steeper rise in $\mathrm{T}-\mathrm{OH}$ and CAT activities. Also, the development of T-OH-specific activity did not reach a plateau during adulthood.

\section{Effects of postnatal castration}

Postnatal male rats 10-1 $1 \mathrm{~d}$ of age underwent either sham operations or bilateral castration and the time courses for developmental deficits in postsynaptic $\mathrm{T}-\mathrm{OH}$ and ganglionic CAT activities were examined. At postoperative weeks 1-12, groups of 8 animals were killed and the PG assayed for enzyme activities and total ganglion protein. At all time points the development of T-OH activity, CAT activity, and ganglion protein was significantly reduced. Over the 12 week postoperative observation period, CAT activity and total ganglion protein continued to develop, but at a diminished rate. In contrast, T-OH activity failed to develop following neonatal castration (Fig. 3). Since maturation of T-OH activity failed to occur, while protein continued to develop, T-OH-specific activity was significantly reduced (Fig. 4). CAT-specific activity was also significantly reduced at all time points (Fig. 4).

Testosterone replacement therapy. Earlier studies determined
TYROSINE HYDROXYLASE ACTIVITY
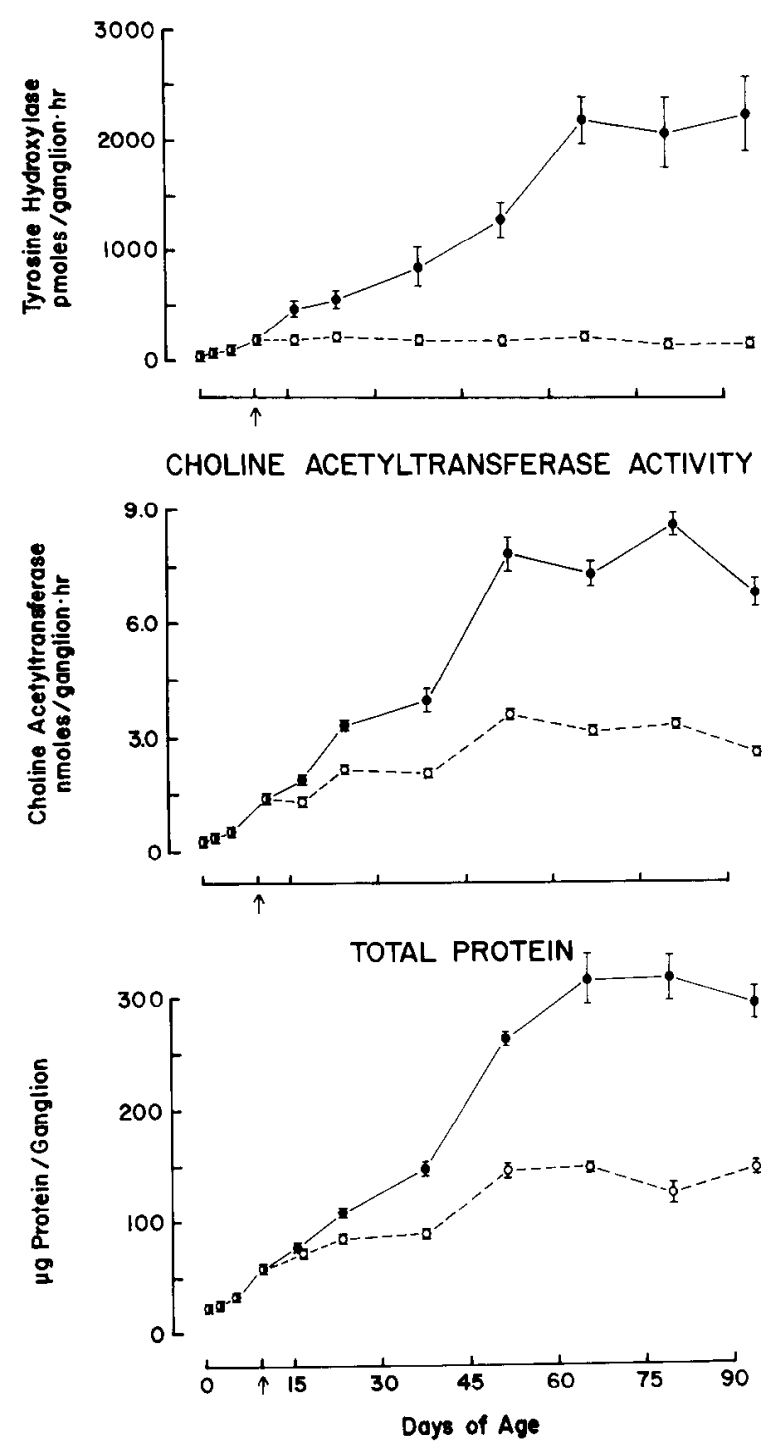

Figure 3. Time course of the effect of castration on the development of tyrosine hydroxylase and choline acetyltransferase activities and total protein in the major pelvic ganglion. Postnatal rats were castrated at $10-11 \mathrm{~d}$ of age and littermates underwent sham operation. At various time points between 1 and 12 postoperative weeks, 8 animals in each group were killed and ganglion enzyme activities and total protein determined. T-OH activity is expressed as pmol/ganglion $\cdot \mathrm{hr} \pm \mathrm{SEM}$. CAT activity is expressed as nmol/ganglion $\cdot \mathrm{hr} \pm \mathrm{SEM}$. Total protein is expressed as $\mu \mathrm{g}$ protein + SEM. Arrow indicates castration at day 10; broken line, castrated males; solid line, control males. All groups differ from controls by at least $p<0.05$.

that the testosterone dosage that was employed maintains androgen-responsive target tissue (e.g., seminal vesicle and vas deferens) wet weight and protein content, as well as ganglion enzyme activity in another hormonally responsive ganglion, the HG (Hamill and Guernsey, 1983; Hamill et al., 1984). Testosterone decanoate $(20 \mathrm{mg} / \mathrm{kg})$ was administered to male rats following castration at 10-11 d of age and every 2 weeks thereafter for 12 weeks. Sham-operated and castrated controls received vehicle only. T-OH and CAT activities were assayed in ganglia from groups of 8 animals each after 12 postoperative weeks to determine whether testosterone replacement could reverse the biochemical developmental deficits observed following post- 


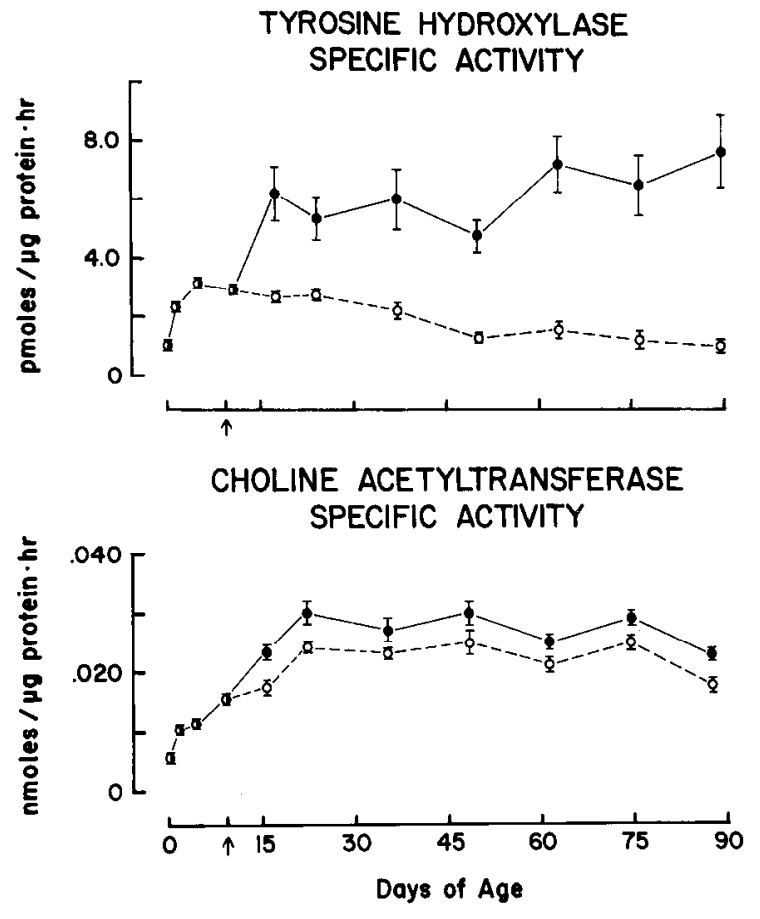

Figure 4. Effect of bilateral castration on the development of tyrosine hydroxylase- and choline acetyltransferase-specific activities in the major pelvic ganglion. Postnatal rats were castrated at $10-11 \mathrm{~d}$ of age and littermates underwent sham operation. At various time points between 1 and 12 postoperative weeks, 8 animals in each group were killed and ganglion enzyme-specific activities determined. T-OH-specific activity is expressed as $\mathrm{pmol} / \mu \mathrm{g}$ protein $\cdot \mathrm{hr} \pm \mathrm{SEM}$. CAT-specific activity is expressed as $\mathrm{nmol} / \mu \mathrm{g}$ protein $\cdot \mathrm{hr} \pm \mathrm{SEM}$. Arrow indicates castration at day 10; broken line, castrated males; solid line, control males. All groups differ from controls by at least $p<0.05$.

natal castration. $\mathrm{T}-\mathrm{OH}$ and CAT activities were fully restored to normal levels by testosterone treatment (Fig. 5). Neonatal castration resulted in $94 \%$ less $\mathrm{T}-\mathrm{OH}$ activity, while $70 \%$ less activity was observed for CAT activity (Fig. 5). In addition, the activity of DDC, an enzyme necessary for the synthesis of catecholamines, which is regulated differently from T-OH (Black et al., 1971b), failed to develop normally following castration ( $70 \%$ less than control). DDC enzyme activity was also restored to normal after treatment with gonadal steroids (Fig. 5). The levels of total ganglion protein were less affected by castration than were enzyme activities; thus, T-OH-, CAT-, and DDC- (not shown) specific activities were reduced. Testosterone replacement also restored enzyme-specific activities to normal (data not shown).

\section{Discussion}

Recent evidence suggests that the development of neural pathways associated with sexual behavior and reproduction in the central nervous system are regulated by gonadal hormones (see reviews: McEwen and Parsons, 1982; Arnold and Gorski, 1984; McEwen et al., 1984). The influcncc of gonadal hormones on developing neural pathways is not limited to the CNS but in fact appears to apply to the peripheral nervous system as well (Dibner and Black, 1978; Partanen and Hervonen, 1979a, b; Suzuki et al., 1982; Wright and Smolen, 1983a, b; Melvin and Hamill, 1986). For instance, testosterone appears to influence biochemistry, neuron number and synapse number in the su-
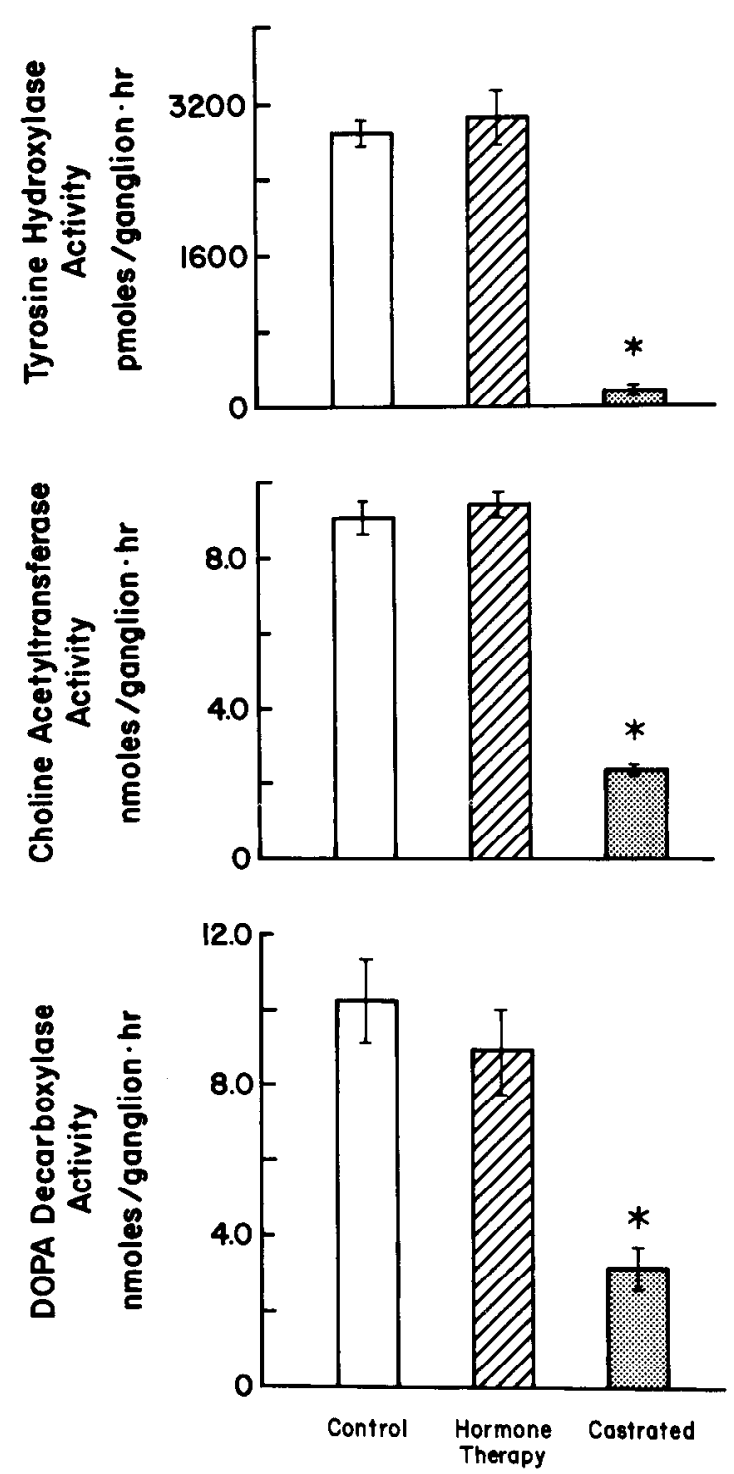

Figure 5. Effect of testosterone replacement on tyrosine hydroxylase, DOPA decarboxylase, and choline acetyltransferase activities in the major pelvic ganglion. Postnatal rats were castrated at $10-11 \mathrm{~d}$ of age and sham-operated littermates served as controls. Control animals received vehicle and castrated animals received vehicle or testosterone decanoate $(20 \mathrm{mg} / \mathrm{kg})$ every 2 weeks until they were killed at 12 postoperative weeks. Eight animals in each group were killed and $\mathrm{T}-\mathrm{OH}$, $\mathrm{DDC}$, and CAT activities determined. T-OH activity is expressed as $\mathrm{pmol} / \mathrm{ganglion} \cdot \mathrm{hr} \pm \mathrm{SEM}$. CAT and DDC activities are expressed as $\mathrm{nmol} /$ ganglion $\cdot \mathrm{hr} \pm \mathrm{SEM}$. ${ }^{*}$, Differs from all other groups by at least $p<0.05$.

perior cervical ganglion (Dibner and Black, 1978; Wright and Smolen, 1983a, b). In addition, the sympathetic hypogastric ganglion $(\mathrm{HG})$ is dependent on testosterone both for adult maintenance (Hamill et al., 1984) and the development (Melvin and Hamill, 1986) of neurotransmitter-synthesizing enzymes. Therefore, it was of interest to examine the role of testosterone on the development of neurotransmitter-synthesizing enzymes in a primarily parasympathetic ganglion, the PG. Initial studies defined the normal development of T-OH and CAT activities in the PG. The PG, similar to ganglia such as the $\mathrm{HG}$ (Melvin and Hamill, 1986) and the sympathetic L-6 (Hamill et al., 1977), does not mature in terms of neurotransmitter-synthesizing enzyme activities until after puberty, which occurs at approxi- 
mately $35 \mathrm{~d}$ of age in male rats. Enzyme activities in the PG, $\mathrm{HG}$, and L-6 ganglia do not reach adult levels until at least 60 $\mathrm{d}$ of age, coinciding with the attainment of adult levels of plasma testosterone (Resco et al., 1968), which suggests that circulating testosterone may regulate neurotransmitter function.

As in the sympathetic HG, postnatal castration at days 10 11 prevented the normal development of the major pelvic ganglion. Postsynaptic T-OH activity failed to develop beyond the $10 \mathrm{~d}$ precastration value. Since total ganglion protein continued to develop, a correspondingly significant loss in T-OH-specific activity was noted. Although noradrenergic markers such as $\mathrm{T}-\mathrm{OH}$ may appear in cholinergic neurons under experimental conditions (Bjorklund et al., 1985), the observed T-OH values probably reflect alterations in the noradrenergic component of the PG. Various regulatory mechanisms could produce the effects of castration on total and specific T-OH activities. A direct effect on the genome by gonadal steroids has been implicated in other systems (O'Malley and Means, 1974) and could explain the loss of T-OII-specific activity. The interaction of steroidreceptor complexes with the genome, which alters transcription rates, has been suggested as the mechanism for other neurotransmitter enzyme systems (Luine et al., 1980a, b). Additionally, testosterone could act directly as a trophic factor. It has the ability to induce sprouting from neural explants in the absence of target tissue (Toran-Allerand, 1976, 1980) and to stimulate regeneration of the hypoglossal nerve following nerve resection (Yu and Srinivasan, 1981; Yu, 1982). Conversely, an indirect effect due to a retrogradely transported trophic factor from target organs (Wakade and Kirpekar, 1973) similar to the NGF mechanism seen with the superior cervical ganglion (Hendry and Iversen, 1972; Iversen et al., 1975) and dorsal root ganglion (Levi-Montalcini and Angeletti, 1963) could produce this phenomenon.

Following castration, ganglionic CAT activity and total protein continued to develop but at a diminished ratc. The development of CAT activity was affected to a greater extent by castration than was total ganglion protein; thus CAT-specific activity was significantly reduced at all time points (Fig. 4). By contrast, the sympathetic HG showed no change in CAT-specific activity subsequent to castration (Melvin and Hamill, 1986). Morphometric analyses of the $\mathrm{HG}$ after castration demonstrated that the reduced levels of CAT activity were related to decreased cell size, suggesting that cell surface area may regulate the number of sympathetic presynaptic terminals (J. E. Melvin, R. W. Hamill, and T. H. McNeill, unpublished observations). The differing effects of postnatal castration on CAT-specific activity in the 2 ganglia could be due to the different makeup of the principal cells. The sympathetic HG (J. E. Melvin, A. Hervonen, T. H. McNeill, and R. W. Hamill, unpublished observations), like the superior cervical ganglion (Yamauchi et al., 1973), appears to be composed predominantly of noradrenergic cell bodies, while the PG is a mixed ganglion with large numbers of both noradrenergic and cholinergic cell bodies (Dail et al., 1975). Therefore, a reduction in CAT-specific activity in the PG might not solely reflect an effect on the sympathetic preganglionic terminals, as would be suggested in the HG. The reduced levels of CAT-specific activity in the PG might also indicate a loss of parasympathetic presynaptic terminals and/or reduced levels of CAT activity in the parasympathetic postganglionic cell bodies. Thus, decreased levels of CAT-specific activity suggest that both the parasympathetic and sympathetic components of the PG are sensitive to gonadal hormones.
Testosterone replacement therapy reversed the effects of castration on the activities of the catecholamine-synthesizing enzymes T-OH and DDC, and restored ganglionic CAT activity to normal. Subsequent to castration, immediate and delayed testosterone replacement in the $\mathrm{HG}$ also restored enzyme activities to normal, suggesting an activational effect by testosterone after day 10 (J. E. Melvin, R. W. Hamill, and T. H. McNeill, unpublished observations). Thus, restoration of PG enzyme activities by testosterone replacement probably implies an activational effect as well. Postnatal castration reduced DDA activity by $70 \%$ of the PG control value, while T-OH activity decreased by $94 \%$. These values are virtually identical to the results obtained in the HG studies (Melvin and Hamill, 1986), suggesting that catecholamine-synthesizing enzymes in the $\mathrm{HG}$ and $\mathrm{PG}$ are similarly regulated by gonadal hormones. In addition, previous studies suggested that T-OH and DDC activities were regulated differently. Different developmental profiles in the superior cervical gangion (Thoenen et al., 1972), divergent responses to spinal cord transection in the L-6 ganglion (Hamill et al., 1977), and separate effects of reserpine treatment in the superior cervical ganglion and adrenals (Black et al., 1971b) all suggest that separate mechanisms regulate T-OH and DDC activities. Thus, the different magnitude of effects produced by neonatal castration on T-OH and DDC activities in the PG may also support different regulatory mechanisms for these 2 enzymes. However, since various cell types in the ganglion may possess DDC activity and not be hormonally responsive, other possibilities may exist.

The present neonatal studies demonstrate that the postnatal neurochemical development of the sexually dimorphic PG (Greenwood et al., 1985) is regulated by gonadal hormones, and that these effects appear to be secondary to the activational effects of testosterone after day 10 of life. Similar activational roles of gonadal hormone have been demonstrated in other ncural systcms (Kizcr et al., 1976; Luine et al., 1977, 1980a, b; Wallis and Luttge, 1980). Viewed together with previous studies in the hypogastric ganglia (Hamill and Guernsey, 1983; Hamill et al., 1984; Melvin and Hamill, 1986), these current investigations in the PG indicate that gonadal hormones exert powerful effects on the regulation of neurotransmitter-synthesizing enzymes, and therefore neural function, in pelvic autonomic ganglia. Thus, these peripheral autonomic ganglia provide convenient models for the study of neuroendocrine regulation of peripheral neuronal systems.

\section{References}

Arnold, A. P., and R. A. Gorski (1984) Gonadal steroid induction of structural sex differences in the central nervous system. Annu. Rev. Neurosci. 7: 413-442.

Bjorklund, H., T. Hokfelt, M. Goldstein, L. Terenius, and L. Olson (1985) Appearance of the noradrenergic markers tyrosine hydroxylase and neuropeptide $Y$ in cholinergic nerves of the iris following sympathectomy. J. Neurosci. 5: 1633-1640.

Black, I. B. (1975) Increased tyrosine hydroxylase activity in frontal cortex and cerebellum after reserpine. Brain Res. 95: 170-176.

Black, I. B., and S. C. Geen (1973) Trans-synaptic regulation of adrenergic neuron development: Inhibition by ganglionic blockage. Brain Res. 63: 291-302.

Black, I. B., I. $\Lambda$. Hendry, and L. L. Iversen (1971a) Trans-synaptic regulation of growth and development of adrenergic neurons in a mouse sympathetic ganglion. Brain Res. 34: 229-240.

Black, I. B., I. A. Hendry, and L. L. Iversen (1971b) Differences in the regulation of tyrosine hydroxylase and DOPA decarboxylase in sympathetic ganglia and adrenals. Nature 231: 27-29. 
Black, I. B., I. A. Hendry, and L. L. Iversen (1972) Effects of surgical decentralization and nerve growth factor on the maturation of adrenergic neurons in a mouse sympathetic ganglion. J. Neurochem. 19: $1367-1377$.

Dail, W. G., P. E. Evan, and H. R. Eason (1975) The major ganglion in the pelvic plexus of the male rat. Cell Tissue Res. 159: 49-62.

Dibner, M. D., and I. B. Black. (1978) Biochemical and morphological effects of testosterone treatment on developing sympathetic neurons. J. Neurochem. 30: 1479-1483.

Fonnum, F. (1969) Radiochemical micro assays for the determination of choline acetyltransferase and acetylcholinesterase activities. Biochem. J. 115: 465-472.

Fonnum, F. (1975) A rapid radiochemical method for the determination of choline acetyltransferase. J. Neurochem. 24: 407-409.

Greenwood, D., R. E. Coggeshall, and C. E. Hulsebosch (1985) Sexual dimorphism in numbers of neurons in the pelvic ganglia of adults rats. Brain Res. 340: 160-162.

Hamill, R. W., and L. A. Guernsey (1983) Hormonal regulation of sympathetic neuron development: The effects of neonatal castration. Dev. Brain Res. 11: 303-307.

Hamill, R. W., E. M. Bloom, and I. B. Black (1977) The effect of spinal cord transection on the development of cholinergic and adrenergic sympathetic neurons. Brain Res. 134: 269-278.

Hamill, R. W., C. J. Earley, and L. A. Guernsey (1984) Hormonal regulation of adult sympathetic neurons: The effects of castration on tyrosine hydroxylase activity. Brain Res. 299: 331-337.

Hendry, I. A., and L. L. Iversen (1972) The effects of nerve growth factor and ganglion blockage on the normal development of the superior cervical ganglion in the mouse. In Proceedings of the Vth Congress of Pharmacology, San Francisco, p. 100.

Hervonen, A., L. Kanerva, R. Lietzen, and S. Partanen (1972) Effects of steroid hormones on the differentiation of the catecholamine storing cells of the paracervical ganglion of the rat uterus. Z. Zellforsch. 134: 519-527.

Iversen, L. L., K. Stockel, and H. Thoenen (1975) Autoradiographic studies of the retrograde axonal transport of nerve growth factor in mouse sympathetic neurons. Brain Res. 88: 37-43.

Kizer, J. S., E. Muth, and D. M. Jacobowitz (1976) The effect of bilateral lesions of the ventral noradrenergic bundle on endocrineinduced changes of tyrosine hydroxylase in the rat median eminence. Endocrinology 98: 886-893.

Lamprecht, F., and J. T. Coyle (1972) DOPA decarboxylase in the developing rat brain. Brain Res. 41: 503-506.

Langworthy, O. R. (1965) Innervation of the pelvic organs of the rat. Inv. Urol. 2: 491-511.

Levi-Montalcini, R., and P. U. Angeletti (1963) Essential role of the nerve growth factor in the survival and maintenance of dissociated sensory and sympathetic embryonic nerve cells in vitro. Dev. Biol. 7: 653-659.

Lowry, O. H., H. J. Roseborough, A. L. Farr, and R. J. Randall (1951) Protein measurement with folin phenol reagent. J. Biol. Chem. 193: 265-275.

Luine, V. N., B. S. McEwen, and I. B. Black (1977) Effect of 17Bestradiol on hypothalamic tyrosine hydroxylase activity. Brain Res. 120: 188-192.

Luine, V. N., D. Park, T. Toh, D. Reis, and B. McEwen (1980a) Immunochemical demonstration of increased choline acetyltransferase concentration in rat preoptic area after estradiol administration. Brain Res. 191: 273-279.

Luine, V. N., F. Nottenbohm, C. Harding, and B. S. McEwen (1980b)
Androgen affects cholinergic enzymes in syringeal motor neurons and muscle. Brain Res. 193: 89-107.

McEwen, B. S., and B. Parsons (1982) Gonadal steroid action on the brain: Neurochemistry and neuropharmacology. Annu. Rev. Pharmacol. Toxicol. 22: 555-598.

McEwen, B. S., A. Biegon, C. T. Fischette, V. N. Luine, B. Parsons, and T. C. Rainbow (1984) Toward a neurochemical basis of steroid hormone action. In Frontiers in Neuroendocrinology, Vol. 8, L. Martini and W. F. Ganong, eds., pp. 153-176, Raven, New York.

Melvin, J. E., and R. W. Hamill (1986) Gonadal hormone regulation of neurotransmitter synthesizing enzymes in the developing hypogastric ganglion. Brain Res. 383: 38-46.

O'Malley, B. W., and A. R. Means (1974) Female steroid hormones and target cell nuclei. Science 183: 610-620.

Partanen, M., and A. Hervonen (1979a) The formaldehyde-induced fluorescence of the developing hypogastric (main pelvic) ganglion of the rat. Histochemistry 62: 249-258.

Partanen, M., and Hervonen, A. (1979b) The effect of long-term castration on the histochemically demonstrable catecholamines in the hypogastric ganglion of the rat. J. Autonom. Nerv. Syst. 1: 139-147.

Purinton, P. T., T. F. Fletcher, and W. E. Bradley (1973) Gross and light microscopic features of the pelvic plexus in the rat. Anat. Rec. 175: 697-706

Resco, J. A., H. H. Feder, and R. W. Goy (1968) Androgen concentrations in plasma and testis of developing rats. J. Endocrinol. 40: 485-491.

Suzuki, Y., H. Ishii, H. Furuya, and Y. Arai (1982) Developmental changes of the hypogastric ganglion associated with the differentiation of the reproductive tracts in the mouse. Neurosci. Lett. 32: 271-276.

Thoenen, H., R. Kettler, and A. Saner (1972) Time course of the development of enzymes involved in the synthesis of norepinephrine in the superior cervical ganglion of the rat from birth to adult life. Brain Res. 40: 459-468.

Toran-Allerand, C. D. (1976) Sex steroids and the development of the newborn mouse hypothalamus and preoptic area in vitro: Implications for sexual differentiation. Brain Res. 106: 407-412.

Toran-Allerand, C. D. (1980) Sex steroids and the development of the newborn mouse hypothalamus and preoptic area in vitro II. Morphological correlates and hormonal specificity. Brain Res. 189: 413427.

Wakade, A. R., and S. M. Kirpekar (1973) "Trophic" influence on the sympathetic nerves of the vas deferens and seminal vesicle of the guinea pig. J. Pharmacol. Exp. Ther. 186: 528-536.

Wallis, C. J., and W. Luttge (1980) Influence of estrogen and progesterone on glutamic acid decarboxylase activity in discrete regions of rat brain. J. Neurochem. 34: 609-613.

Wright, L. L., and A. J. Smolen (1983a) Neonatal testosterone treatment increases neuron and synapse numbers in male rat superior cervical ganglion. Dev. Brain Res. 8: 145-153.

Wright, L. L., and A. J. Smolen (1983b) Effects of 17- $\beta$-estradiol on developing superior cervical ganglion neurons and synapses. Dev. Brain Res. 6: 299-303.

Yamauchi, A., T. Lever, and K. Kemp (1973) Catecholamine loading and depletion in the rat superior cervical ganglion. J. Anat. 114: 271282.

$\mathrm{Yu}, \mathrm{W} . \mathrm{A}$. (1982) Effect of testosterone on regeneration of the hypoglossal nerve in rats. Exp. Neurol. 77: 129-141.

$\mathrm{Yu}$, W. A., and R. Srinivasan (1981) Effect of testosterone and 5xdihydrotestosterone on regeneration of the hypoglossal nerve in rats. Exp. Neurol. 71: 431-435. 